\title{
Sturge Weber syndrome: A case report
}

\section{Síndrome de Sturge Weber: um relato de caso}

\begin{abstract}
Purpose: The Sturge-Weber syndrome (SWS) is a rare congenital disorder that occurs sporadically and features lesions of both skin and nervous system. We report a case of 7 year-old girl with Sturge-Weber syndrome and discuss its clinicopathological features, differential diagnosis and also emphasize the importance of its diagnosis in the clinical oral practice.

Case Description: The classic pathognomonic manifestations include angioma of the leptomeninges extending to cerebral cortex with ipsilateral angiomatous lesions, unilateral facial nevus affecting a division of trigeminal nerve, hemiparesis, intracranial calcification, mental retardation and refractory epilepsy. The most apparent indication of SWS is a facial birthmark or "Port Wine Stain" present at birth and typically involving at least one upper eyelid and the forehead. Management of a patient with Sturge-Weber Syndrome may be challenging due to risk of hemorrhage.

Conclusion: The dentists should focus on comprehensive therapy, starting with behavior management and stress on preventive measures.
\end{abstract}

Key words: Sturge-Weber Syndrome; Portwine stain; encephalotrigeminal syndrome; oral mucosa

\section{Resumo}

Objetivo: A síndrome de Sturge-Weber (SWS) é uma rara doença congênita que ocorre esporadicamente e apresenta lesões de pele e do sistema nervoso. Este artigo é um relato de caso de uma menina de 7 anos com SWS para discutir suas características clinicopatológicas, diagnóstico diferencial e enfatizar a importância do seu diagnóstico na prática clínica odontológica.

Descrição do caso: As manifestações clássicas patognomônicas incluem angioma das leptomeninges que se estendem para o córtex cerebral com lesões angiomatosas ipsilaterais, nevo facial unilateral, que afetam uma divisão do nervo trigêmeo, hemiparesia, calcificação intracraniana, retardo mental e epilepsia refratária. A indicação mais evidente de SWS é uma marca de nascença facial ou "mancha vinho do porto" presente no nascimento e tipicamente envolvendo pelo menos uma pálpebra superior e a testa. O controle clínico de um paciente com SWS pode ser desafiador devido ao risco de hemorragia.

Conclusão: Os dentistas devem adotar uma abordagem terapêutica abrangente, começando com o controle de comportamento e de estresse com medidas preventivas.

Palavras-chave: Síndrome de Sturge-Weber; angiomatose encefalotrigeminal; mucosa bucal

\section{Pournima Godge a \\ Shubhra Sharma a \\ Monica Yadava \\ Pallavi Patil b \\ Sandeep Kulkarni a}

\begin{abstract}
a Dept of Oral and Maxillofacial Pathology, Terna Dental College and Hospital, Navi Mumbai, Nerul, India

b Dept of Periodontology, VYWS Dental College and Hospital, Amravati, Maharashtra, India
\end{abstract}

\author{
Correspondence: \\ Pournima Godge \\ Terna Dental College \\ Phase-II,Sector-22 \\ Nerul-W-400607 \\ Navi Mumbai (Maharashtra) - India \\ E-mail: pournimagodge@rediffmail.com
}

Received: September 2, 2011

Accepted: November 14, 2011

Conflict of Interests: The authors state that there are no financial and personal conflicts of interest that could have inappropriately influenced their work.

Copyright: (c) 2011 Godge et al.; licensee EDIPUCRS. This is an Open Access article distributed under the terms of the Creative Commons AttributionNoncommercial-No Derivative Works 3.0 Unported License. 


\section{Introduction}

Sturge-Weber syndrome (SWS), or Encephalo-trigeminal angiomatosis, is a rare, congenital neurocutaneous syndrome characterized by unilateral facial cutaneous vascular malformation (nevus flammeus or port-wine stain) in association with ipsilateral leptomeningeal angiomatosis. First described by Schirmer and later more specifically by Sturge in 1879, it is also known as Sturge Weber disease, leptomeningofacial angiomatosis, Sturge-Weber-Dimitri syndrome, etc $(1,2)$. Inspite of being uncommon, this is the most frequent disease among the neurocutaneous syndromes - specially with vascular predominance, with a prevalence of 1/50,000 live births and no racial bias (2). Although its etiology is unknown, it is believed that it is caused by the abnormal persistence of an embryonal vascular system which is localized around the cephalic region of the neural tube (3).This syndrome occurs almost entirely sporadically and with equal frequency in both sexes. Intraorally, angiomatosis can involve lips causing macrochelia, resulting in hemihypertrophy of the buccal mucosa, palate and the floor of the mouth. Gingival involvement can vary from light vascular hyperplasia to monstrous overgrowth making closure almost impossible (4). In this paper we report a case of a patient affected by SWS presenting with classical clinical manifestations and emphasize the importance of an accurate diagnosis and management in the clinical oral practice.

\section{Case history}

A 7 yr old girl reported to the department with complaints of swollen and bleeding gums. Her past medical history revealed right focal seizures since 3 months of age. She started having reflex seizures on a daily basis when she was 2 years old. She was on long term antiepileptic treatment with multiple antiepileptic drugs (phenobarbitone,phenytoin sodium, sodium valproate, clonazepam and topiramate) for intractable seizures. Hematological and biochemical profile was within normal range. The patient was communicative but apprehensive. She was born full term following uneventful birth events. Her family history was non contributory. On general examination the patient had a unilateral portwine stain centered around left forehead, the left eye, side of the nose, left upper lip extending up to to the midline. During the anamnesis, her father revealed that the lesion was present since her childhood with progressive growth and caused slight discomfort when exposed to the sunlight.

Intraoral examination of the patient showed a mixed dentition, with all teeth erupting at normal dental age and no other obvious hard tissue abnormalities. Oral hygiene of the patient was poor with extensive amount of plaque.

Gingiva in the upper anterior region appeared inflammed, reddened with a tendency towards bleeding on probing. However, there was absence of blanching on application of pressure. The buccal mucosa, tongue, floor of the mouth, palate and rest of the gingival appeared normal.
Ophthalmologic examination performed showed no abnormality.

Neurological examination revealed right hemiparesis and neuropsychological assessment revealed an overall borderline to mildly challenged cognitive functioning. MRI BRAIN scan demonstrated left cerebral hemitatrophy, multiple pialangiomatosis, hypertrophied choroids plexuses, left parieto-occipital gliosis with marked leptomeningeal enhancement along left parieto-occipital gyri.

In view of clinical neurological findings and the characteristic MRI brain findings the diagnosis of SturgeWeber syndrome was then established.

The patient was put through a thorough plaque control regimen to minimize gingival enlargement. The treatment adopted consisted of oral prophylaxis carried out every week, use of chlorhexidine mouth rinse, taking plaque index, oral hygiene orientation and motivating the patient at each visit .Considering the possibility of phenobarbitone induced gingival hyperplasia sodium valproate was substituted for treating epilepsy. About one and a half month later, the patient reported decreased bleeding with a slight decrease in the degree of gingival enlargement.

Currently, the patient is under the same plaque control regimen and is regularly followed up. Simultaneously, the patient was referred to the epilepsy surgery centre for work up due to intractable seizure disorder.

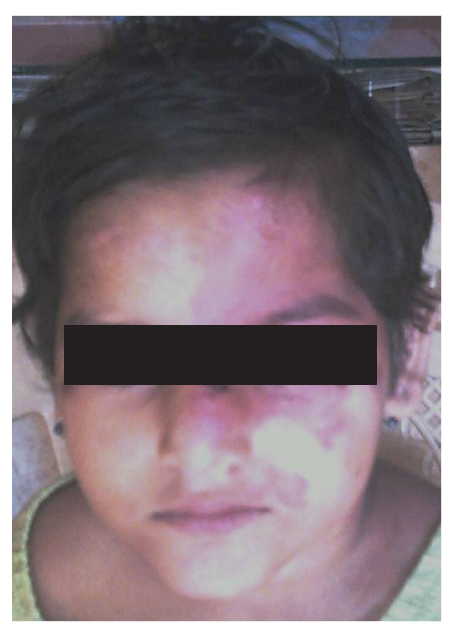

Fig. 1. Clinical picture showing portwine nevus involving the left half of the face and the forehead.

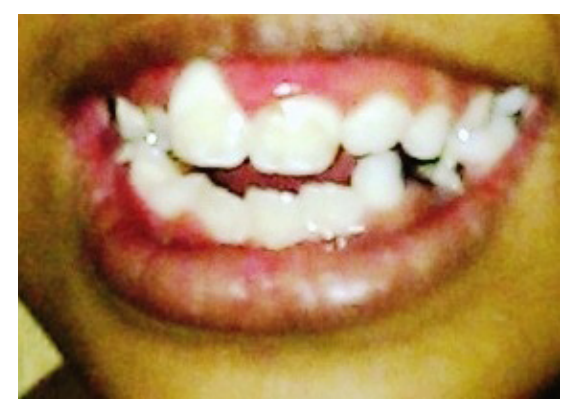

Fig. 2. Clinical picture demonstrating swollen and inflammed and gingiva. 


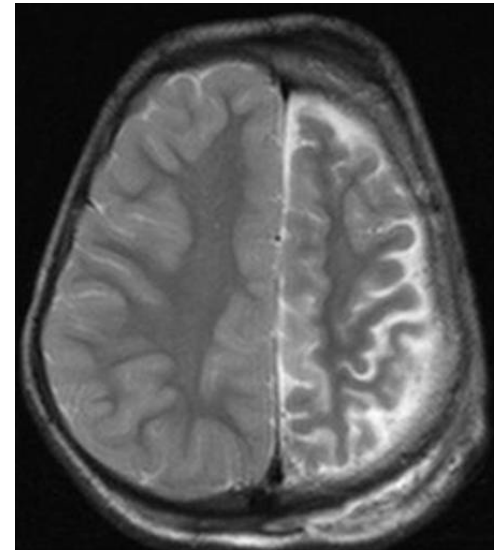

Fig. 3. Scan showing left cerebral hemiatrophy with gliosis of the left parietooccipital area.

Fig. 4. Post contrast scan showing multiple DVA, marked lepomeningeal enhancement and hypertrophied choroid plexus.
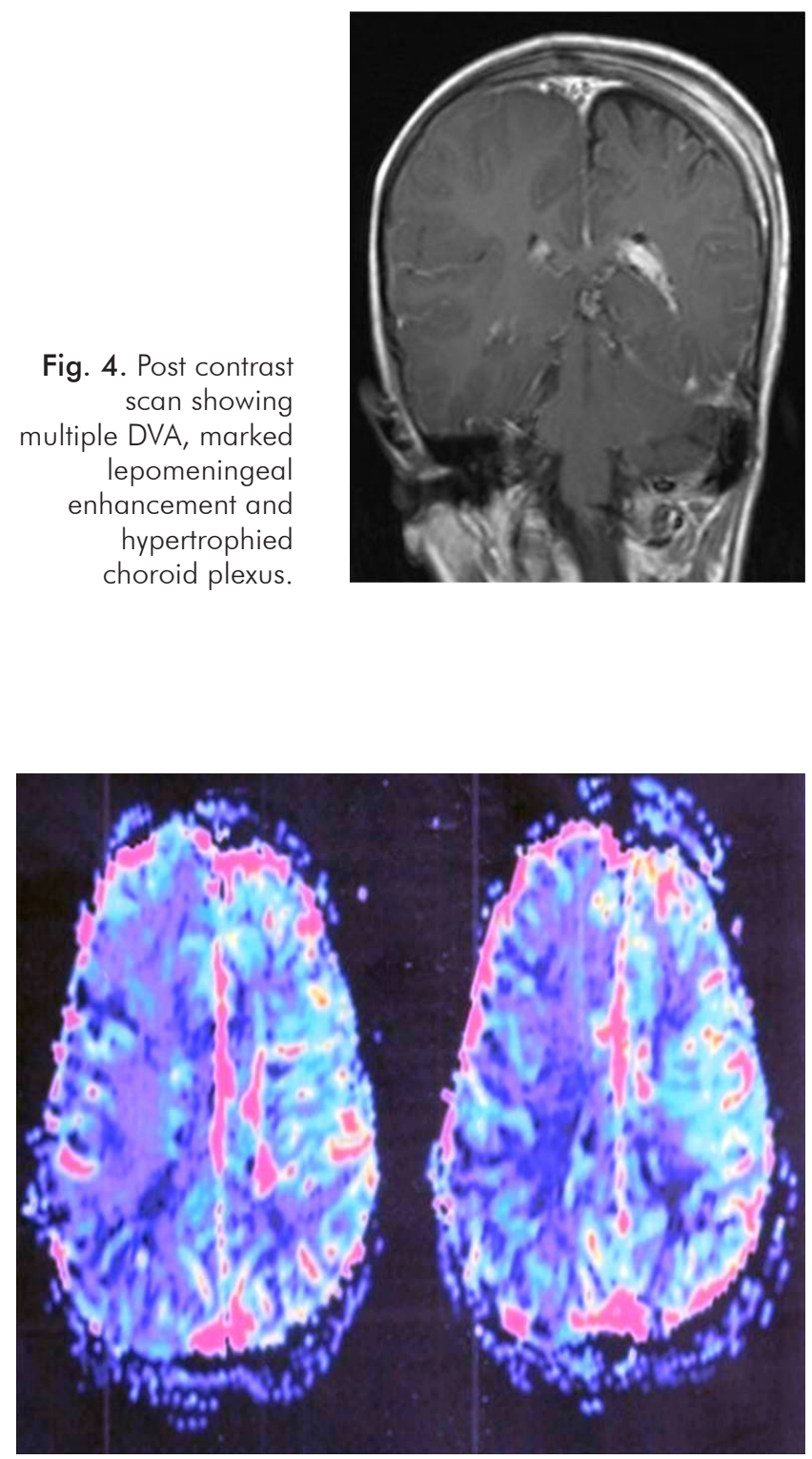

Fig. 5. MR perfusion studies showing marked hypoperfusion of the entire left cerebral hemisphere.

\section{Discussion}

The Sturge-Weber Syndrome was initially described by Schirmer, in 1860, and was later specified by Sturge (1878), who associated the dermatological and ophthalmic changes to the disease's neurological manifestations. In 1992, Weber complemented it through the documentation of these patients cerebral radiologic alterations (2).

The inheritance of Sturge-Weber syndrome is sporadic and it occurs with a frequency of 1:50,000 (1). Both the sexes are equally affected and no racial difference has been reported (4).

It is believed that it is caused by the abnormal persistence of an embryonal vascular system, which is localized around the cephalic region of the neural tube (3).

The SWS presents with neurological, cutaneous, ocular and oral manifestations that may (or not) be associated with one another; however the most evident clinical manifestation is the presence of the nevus flammeus or port wine stain on the face, which normally follows the course of branches V1 and $\mathrm{V} 2$ of the trigeminal nerve (2).

According to INAN (1999), the port wine nevus is localized on the face especially over the right side and are detected in 87 to $90 \%$ of the cases. The lesion extension over the middle line is observed in $50 \%$ of the patients and bilateral involvement can be detected in about $33 \%$ of the cases (5). In our case, the patient showed nevus flammeus only on the left side of the face without extension over the middle line.

The ipsilateral leptomeningeal angiomatosis also represents one of the main signs of the syndrome, may present with a progressive nature and commonly leads to cerebral calcifications, epileptic convulsive crises, contralateral hypertrophy, hemiparesis $(30 \%)$ and mental retardation $(50 \%)(2)$. Neurological examination of the patient in our case revealed right hemiparesis, intractable seizures and neuropsychological assessment revealed an overall borderline to mildly challenged cognitive functioning.

The ocular complications manifests as glaucoma and vascular malformations of the conjunctiva, episclera, choroid, and retina (2).

Oral manifestations are present in approximately $38 \%$ of the cases, and they may involve hemangiomatous lesion in the lip, oral mucosa, gum, tongue and palatine region. The oral manifestations are generally unilateral and finish abruptly in the middle line. We observe ipsilateral gingival hyperplasia, characterized by an increase in the vascular component and gingival hemorrhage at minimal traumatisms (2). Gingival enlargement is reported to be often superimposed by dilantin induced gingival hyperplasia. However phenobarbitone can also cause gingival hyperplasia (6). In the present case it should be noted that one of the drug used for treating the patient was phenobarbitone and the finding of absence of blanching on pressure points towards this as a possibility. Further the poor oral hygiene maintenance due to mildly challenged cognitive functioning, may intensify inflammation and gingival hyperplasia . 
The general management of the patient includes control of epilepsy and ocular lesions. Port wine stains on the face can be a cosmetic problem and should be treated by a plastic surgeon. A high dose of hydrocortisone given orally in infancy results in regression of well-localised small lesions. Other methods of treatment include dermabrasion, tattooing, lash lamp pulse tunable dye laser therapy, which can result in partial or complete clearing of the port wine stains $(7,8)$.

The patients with oral changes must be submitted to periodic oral check ups.

The dental rehabilitation of such patients is a complex process, requiring conservative management and may demand the use of behavior management techniques due to mental retardation (9). Achieving hemostasis, can be a significant problem for some cases requiring surgery, enforcing a need for accurate planning and the utilization of techniques to diminish the bleeding. Inspite of strict oral hygiene measures, angiomatous gingival enlargement poses a threat to gingival health and may at some point require gingivectomy.

Differential diagnosis of this syndrome include Klippel Trenauny-Weber syndrome. Hereditary hemorrhagic telengiactasias (Rendu Osler Weber disease), Maffucci's syndrome, Von Hippel Lindau disease. Portwine stains should be differentiated from nevus flammeus neonatorum which occurs as an isolated lesion, pyogenic granuloma and venous varicosities $(2,7)$.

MRI brain with contrast shows abnormal leptomeningeal angiomatosis where as CT scan shows gyriform calcifications. Additional studies such as SPECT and PET studies reveal reduced metabolism of the brain adjacent to leptomeningeal lesion. MRI brain findings in our patient was similar to what has been mentioned in the literature. The seizures are usually refractory to treatment and they usually require a surgical treatment hemispherectomy.

\section{Conclusion}

Management of a patient with SWS may be challenging due to risk of hemorrhage. The parents of all the diagnosed patients must receive counseling concerning the potential risk of affected offspring. The health professionals have to be suitably able to recognize its characteristic signs and symptoms, and so improve the quality of life of these. The dentists should focus on comprehensive therapy, starting with behavior management and stress on preventive measures as with any patient with developmental disabilities.

References 1. Zaroff CM, Isaacs K. Neurocutaneous syndromes: behavioral features. Epilepsy Behav 2005;7:133-42.

2. Neto FXP, Junior MAV, Ximenes LS, Jacob CCS, Junior AGR, Palheta CP et al. Clinical features of Sturge-Weber syndrome. Arq. Int. Otorrinolaringol 2008;12:565-70.

3. Aydin A, Çakmakçi H, Kovanlikaya A, Dirik E. Sturge-Weber syndrome without facial nevus. Pediatr Neurol 2000; 22:400-2.

4. Ahluwalia TPS, Lata J, Kanwa P. Sturge-Weber syndrome with intraoral manifestations: A case report. Indian J Dent Res 1998;9:140-5.

5. Inan CJM. Sturge-Weber syndrome: report of an unusual cutaneous distribution. Brain Develop 1999;21:68-70.

6. Phenobarbitone induced gingival over growth report of two cases and complications in management. J Dent Child 1996;63:408-13.

7. Saddan NS, Wolach B. Treatment of hemangiomas of infants with high doses of prednisone. J Pediatr 1996;128:141-6.

8. Suprabha BS, Baliga M. Total oral rehabilitation in a patient with portwine stains. J Indian Soc Pedod Prev Dent 2005;99-102.

9. Parrish JM. Behaviour management in child with developmental disabilities. Pediatr Clin North Am 1993;40:617-28. 